\title{
Fostering Civic Agency in an American Government Course
}

\author{
Daniel J. Mallinson, Ph.D. ${ }^{1}$ \\ Assistant Professor of Public Policy and Administration \\ Penn State Harrisburg \\ Laura Cruz, Ph.D. \\ Associate Research Professor \\ Schreyer Institute for Teaching Excellence
}

Scholars and commentators are increasingly concerned about the erosion of democratic norms in the United States. Political science education stands at the forefront of higher education's mission to create an educated citizenry, and civic education is linked to outcomes like civic engagement and trust in government. Much of the research on civic education, however, examines how different classroom interventions affect students' intentions of engaging civically in the future. This study argues that between intention and action lies agency. Specifically, it examines whether an introductory course in American government increases civic agency. A new scenario-based method of measuring civic agency is also introduced. The study finds that civic agency does in fact increase, with students sharpening their calculus of engagement. They better understand where they can best engage and how. Increasing agency lays the foundation for future engagement when students care about an issue enough to weigh in.

Keywords: civic engagement, civic agency, American government, active learning

\footnotetext{
${ }^{1}$ Corresponding Author. Penn State Harrisburg. 777 W. Harrisburg Pike. Middletown, PA 17057.
} mallinson@psu.edu. 
A rapidly changing world abroad and concerns about democratic erosion in the United States (Carey et al. 2019) reinforces the push within political science for a better-educated and more engaged citizenry. While the American Political Science Association has had a concern for civic education at the forefront since its founding (McCartney et al. 2013), an effort emerged in the last decade to provide greater resources, increased scholarly attention, and even a new scholarly home for civic engagement scholars within the discipline (Matto et al. 2017; Levine 2019). A perennial question, however, is how to best foster civic engagement among undergraduate students. Those who choose a political science major are typically there because they have the motivation to affect positive change through politics. Introductory survey courses in subjects like American government, comparative politics, and international relations offer a different audience, and thus, opportunity. The discipline can leverage these types of courses to have a broader impact in developing an informed citizenry, particularly when institutions of higher education require such courses in their general education curriculum.

This study seeks to better understand how an introductory course can nudge students in the direction towards greater civic efficacy. It is difficult for a single course to bear the responsibility of turning students into active citizens. A single course can, however, lay the groundwork for later action in helping students understand the levers of power that they have access to and how to use them appropriately. This is a civic calculus. To engage politically, individuals need both care and know what they can do to influence the political system. The present study focuses on how an introductory American politics course can do the second by building civic agency, even in one semester. This is done by using both quantitative and qualitative results of a pre- and a post-survey delivered in an introductory American government course. The survey is unique in that it does not ask students about whether they think they would 
engage civically, but it provides them scenarios to consider whether and how they would engage. After briefly reviewing the literature on civic engagement, classroom engagement, and the gap between behavior and intention, the new scenario-based assessment of civic agency is presented. The results of the pre- and post-survey are assessed in two ways: (1) what actions did students propose in response to each scenario and (2) what were their rationales for those actions. Finally, the broader implications of these findings for political science education are discussed.

\section{Bridging the Intention-Action Gap in Civic Engagement}

Concerns regarding American political engagement are myriad. Low rates of electoral participation create a free-rider problem whereby many citizens shirk their responsibility to participate and thus yield power to narrow moneyed interests (Mansbridge 2017). There is a well-document growing distrust in government and fellow citizens, which has in part fed a rise in populism in Western democracies (Rainie and Perrin 2019; Esen and Yardımc1-Geyikçi 2019; Hosking 2019). Civic education is vital in achieving greater trust in government (Barrett and Greene 2017). It is also important for greater global engagement (Lorenzini 2013). Recognizing the importance of civic education for our democratic future, the Association of American Colleges \& Universities and the U.S. Department of Education called for higher education to "reclaim its civic mission" (National Task Force on Civic Learning and Democratic Engagement 2012). Political science programs can be the locus of this effort on many college campuses, as its core coursework informs students about their rights and responsibilities as citizens and the institutions of government. Nevertheless, fostering civic mindedness is trans-disciplinary (Matto et al. 2017).

Many liberal arts programs require at least some exposure to American government and/or American culture and introductory courses in American government often serve as the 
workhorse for these requirements. For non-political science majors, an introductory American government course is the only formal study of government that they will undertake, though informal extracurricular programs offered by political science programs can also increase civic skills (Abernathy and Forestal 2019). Introductory courses, however, provide greater opportunities for reinforcing civic knowledge and agency through repeated classroom interactions, engagement with the material, and engagement with the instructor. Thus, introductory courses should receive special focus regarding their place in fostering a civically minded society. Moreover, there is evidence from the Canadian context that instructors' values regarding civic engagement do not always match the ways they structure introductory courses (Bell and Lewis 2015). The purpose of such an introductory course is typically to introduce students, in broad strokes, to the key formal and informal institutions of American government and individual and collective political behaviors that shape and are shaped by those institutions. Though civic mindedness does not result from a single course, the current study addresses the question of whether such an introductory course can nudge students in the direction of civic engagement.

While civic engagement has long been of interest to educators in political science, research on its integration in the college classroom moved from a trickle to a flood when service and community-based learning were identified as a high impact practice (Jacoby 2009; Kuh 2008). While the two concepts are not synonymous (Bringle and Clayton 2012; Reschly and Christenson 2012), this common identification served as a theoretical bridge connecting civic engagement with student persistence and success, especially for public universities. Measuring the collective impact of civic engagement pedagogies on student success required institutions and super-institutional organizations to develop a range of assessment tools, stretching across 
multiple disciplines, and integrating increasingly nuanced perspectives of the multiple facets of civic and community-oriented learning (Barrett and Zani 2015; Beaumont 2005; Clayton et al. 2012; Goldfinger and Presley 2010; Holland 2014; Musil 2009; Torney-Purta et al. 2015).

In addition to global tools that measure multiple forms of engagement (with civic included, e.g., the National Survey on Student Engagement), researchers have developed specific instruments for capturing civic learning outcomes, including attributes such as knowledge/skills, competencies, attitudes, and behavior (especially participation) (Beaumont et al. 2006; Flanagan et al. 2007; Hatcher 2011; Jacoby 2009; Moely et al. 2002; Reason and Hemer 2015). The latter has proven to be especially elusive to study, as the long-term effects of classroom based interventions are often not realized until after graduation, when it can be difficult to locate subjects; and the wide range of potential activities in which college graduates can become involved make it challenging to capture, much less verify, their behaviors. On one hand, the majority of studies of civic behavior indicate strong correlations between civic engagement activities in the classroom with civic engagement activities outside of the classroom (Colby et al. 2007; Assendelft 2008; Huerta and Jozwiak 2008; Wukich and Siciliano 2014; Elder et al. 2007). On the other hand, most of these studies rely on student or stakeholder self-reporting, including, in some cases, the projection of future behavior (Gould 2011; Latimer and Hempson 2012; Yanus et al. 2015). What researchers have primarily been able to establish, then, is a strong correlation between civic engagement in the classroom and the intention of becoming an active and participatory citizen later in life.

Recent insights into collective human behavior have made note of the psychological gap that can exist between intention and action. The scholarly conversation about the intentionbehavior gap crosses multiple disciplines and often focuses on activities with high intentionality, 
such as increased exercise or lower energy use, and which could be extended to include positive civic actions such as voting (Abel et al. 2019; Anderson et al. 2018; Carrington et al. 2014; Faries 2016; Frederiks et al. 2015; Sheeran and Webb 2016). The issue has also been discussed in relation to other forms of civic education, notably service learning (Liu and Lin 2017; Nicholls and Schimmel 2012) and sustainability (Kollmuss and Agyeman 2002; Pfeiffer et al. 2017). Assuming the existence of a gap between intention and behavior, the salient question becomes why that gap exists and, by extension, what can be done to close it.

Research has shown that the reasons for the intention-behavior gap are complex, varied, and context-dependent, but behavior theorists have noted that between intention and behavior, lies agency, or the perceived ability to "originate and direct actions for given purposes" (Glanz et al. 2008; Malle et al. 2003). Similarly, the concept of agency as mediating between intention and behavior is central to many cognitive theories of learning, notably including those of psychologist Albert Bandura (2006). Following a similar logic, it could be said that between existing studies of civic intention and self-reported civic behavior on the part of college students, lies the potential to study their civic agency, i.e. the capacity to identity and direct actions to achieve desired civic outcomes (Forestiere 2015).

A key to increasing agency, however, is ensuring that students are engaged in the class throughout the entire course. If students are simply passive participants in the course, then it stands to reason that they will not benefit from its content. Researchers have studied how specific activities like service learning (Assendelft 2008), student-directed assignments (Hellwege 2018), problem-solving exercises (Wukich and Siciliano 2014), deliberative dialogue (Latimer and Hempson 2012), or special projects (DeLaet 2016; Yanus et al. 2015) impact self-perceptions of interest in civic engagement and classroom engagement. Student engagement systems like 
iClickers and Nearpod serve a different purpose, but one that should also increase agency. Specifically, they facilitate student engagement with the content of introductory courses in a manner that helps students achieve course learning outcomes (Ivanov 2019). An aspiration for introductory political science courses is that they increase interest in and comfort with being a good citizen, so better achieving those learning outcomes should increase students' ability to engage civically. Thus, this study does not include testing the addition of a novel module or assignment but, instead, how the entire course, including the use of the app-based student engagement software Nearpod, builds civic agency. To that end, this study seeks to measure changes in the degree of civic agency expressed by students after completing an introductory American government class.

This study utilizes an open-ended, scenario-based assessment. A scenario-based assessment was chosen for several reasons. Recent studies in civic engagement have called for a more holistic approach to assessment that extends beyond the use of discrete data, such as likertscale surveys, to include the use of other often qualitative measures, such as portfolios, interviews/focus groups, and ethnographies, with the aim of gaining further insight into motivation (or lack thereof) and related concepts like metacognition (Holland 2014). The use of scenario or case-based assessment also dovetails with trends in authentic classroom assessment (Wiggins 1990), with a particularly strong affinity for Dee Fink's concept of forward-looking assessment (Fink 2003). Finally, scenario-based assessments have also proven to be effective in both public policy and education contexts, particularly in studies focused on projecting behavior into unknown future contexts (Wukich and Siciliano 2014). The methodology of this study and the scenario-based survey used will now be discussed. 


\section{Methodology}

To examine whether an introductory course in American government increases civic agency among students, a study was conducted in one such course in the fall of 2019. This section will briefly describe the course before presenting the novel assessment of civic agency. It concludes with an introduction to the methodology used to analyze patterns in student agency.

\section{Teaching American Government}

The study was embedded within a three-credit introductory course in American government at [university redacted for blind review] in the fall of 2019. This course is a survey of formal and informal political institutions (Congress, the Presidency, the courts, political parties, the media, and interest groups), political behaviors (voting, civil rights and liberties movements, political opinion, and lobbying), and the structure of American government (the Constitution and federalism). It counts towards the general education requirements of the university but is not strictly required. It is, however, a prerequisite for upper-level political science coursework in American government. The course is most often taken by students in their first or second year of attendance. In fall 2019, the course had an enrollment of 50. The course was split 50-50 male and female. In terms of class standing, 54 percent of the students were in their first year (in terms of earned credits), 20 percent in their second year, 12 percent in their

third year, and 14 percent in their fourth year. A total of 72 percent were undeclared or premajors. Only three students were declared public policy or political science majors. The remaining majors included business administration (1), criminal justice (2), health policy and administration (5), management (1), psychology (3), security and risk analysis (2). Of the premajors, eight were in liberal arts, and thus some of them may eventually declare political science as a major. 
Assessment in the course included both factual knowledge and application of civic skills. Factual knowledge was assessed using periodic quizzes. The students also completed a series of practical citizenship-related exercises: (1) identifying the correct public officials to contact with certain problems; (2) learning how to register to vote and how to follow through with voting; (3) writing an opinion editorial; and (4) drawing Congressional districts in Pennsylvania (gerrymandering). ${ }^{2}$ These assignments were specifically chosen to introduce students to civic skills and increase their sense of civic agency.

In addition to the content, an app-based student engagement system called Nearpod was used in the course. ${ }^{3}$ Like iClickers and other hand-held response systems (Baumann et al. 2015), programs like Nearpod, Mentimeter, and Echo 360 help students engage with class content in ways that are not possible in large courses (Mayhew 2019; Ivanov 2019). While clickers allow students to answer questions (often multiple choice) proposed by the professor, Nearpod offers a suite of engagement features that are deployed via student laptops, tablets, or smartphones. Instructors integrate activities with slides that can be created in PowerPoint, LaTeX, Google Slides, or the Nearpod interface. Tools used in this course included a collaborate function that allowed all students to respond to a question with Post-It note-sized answers, open-ended questions, class polls, and embedded video content. Many of these were combined with traditional teaching methods like think-pair-share. The software provided all students the opportunity to engage with the course material and the instructor, regardless of whether they choose to speak openly in the course.

\footnotetext{
${ }^{2}$ https://drawthelinespa.org/.

3 www.nearpod.com
} 


\section{Assessing Civic Agency}

The expression of civic agency first requires a student to be able to identify appropriate actions. To assess this skill, a series of four scenarios were devised that warrant civic action and asked students to identify what actions, if any, they would take in response to each situation. Rather than utilize a pre-determined list of choices, students were asked to articulate a specific action using an open-ended response option. The scenarios were scaffolded to encompass multiple levels of civic engagement, ranging from the campus to the country, each of which required the identification of a different set of behaviors.

The second attribute of civic agency, the ability to direct actions to achieve a given purpose or goal, was assessed by asking students to explain the reasoning behind their chosen action, also using an open-ended response question. The scenarios were intentionally framed to allow for multiple pathways, depending on attitudes concerning the issue at hand. In other words, the scenarios were not predicated on a "right" answer, nor did they require or suggest that students hold specific political beliefs or values. It was our intention to give them maximal flexibility to direct their actions as they deemed appropriate to the scenario, as well as an attempt to control for values as a contributing factor in directing behavior (Bryant et al. 2012; Lott 2013).

Much of the civic engagement literature relies on scales of anticipated activities (Latimer and Hempson 2012) or student self-assessment about their ability to contact public officials, vote, etc. (Assendelft 2008). Such assessments are likely positively biased, as students know that they should be engaged. The instrument proposed herein and deployed in the course described above assess whether students know what they can do to engage and whether their ideas are legitimate for the venue and problem presented. Students were presented with the following four scenarios: 
1. You think that your campus has serious safety issues that concern you.

2. The county (or city) where you live has proposed to build a highway in a place where you think it will do harm.

3. The Pennsylvania state legislature is considering a bill to legalize medical marijuana across the state of Pennsylvania.

4. The United States Supreme Court is considering a case involving physician-assisted suicide (e.g., euthanasia, death with dignity).

For each scenario, students were asked to "Please describe what actions (if any) you would take in response to this issue" and "Please provide a brief explanation of your response to this scenario. Why did you choose the response that you did?" The questions vary the venue, and thus the appropriate action(s) that students can take in response to the issues. Thus, the questions not only assess whether students have the agency to propose action, but also whether they have the knowledge to direct that agency effectively.

These scenarios and questions, as well as basic demographic questions, were provided to participants in a pre- and a post-survey at the beginning of the course and at its conclusion. The study was exempted by the [university redacted for blind review] Institutional Review Board on August 13, 2019. Participants provided informed consent to university staff in the Center for Teaching Excellence prior to taking the pre-survey and the instructor did not know which students were participating. Additionally, the students completed the surveys anonymously. Participants did not necessarily respond to all four scenarios and several participants who consented and took the pre-survey did not complete the post-survey. This is apparent in the sample sizes reported in the results below. 


\section{Analyzing Proposed Student Actions and Motivations}

The two researchers worked together to develop a coding scheme for the types of actions proposed by students in response to the four scenarios. Each independently developed a list of common types of actions before sharing and identifying common patterns among their coding schemes. This resulted in the following seven categories of student actions: (1) nothing; (2) educate; (3) individual action (personal); (4) individual action (solution oriented); (5) contact local authorities; (6) contact other authorities; (7) build consensus. Actions falling into educate include both educating themselves and others on the topic. Personal individual actions include things that are not oriented towards solving the problem, but are students responding personally to the problem. For example, in the public safety on campus scenario, some students reported that they would walk back to their dorm building. Solution-oriented individual actions, on the other hand, include things like protesting. Respondents reporting that they would contact authority figures were sorted into whether the figures were local to the problem (e.g., school administrators, city/county officials, and state representatives in the first three scenarios, respectively) or not local to the problem. For example, a student reported that they would contact the Governor of Pennsylvania to address the campus safety problem. While this is an authority figure, it is not one localized to the scenario's context. Finally, actions involving building consensus include discussions with peers, signing or starting a petition, and more.

In addition to identifying an action, participating students were asked to provide a short rationale for their choices for each scenario. To analyze these qualitative responses, the researchers utilized an emergent coding method that took place in four rounds: two coders first identified themes independently, these themes were then merged, the evidence coded again, and then a final round consisted of reconciling any remaining discrepancies. It should be noted that 
fewer responses were collected in the post-survey overall ( $n=29$ pre, $n=23$ post), so direct numerical comparisons were not, and should not, be drawn. This process produced four persistent themes relevant to student perceptions of their own civic agency, described below.

\section{Results}

\section{Proposed Student Actions}

Table 1 presents the results of the actions that students proposed in response to each scenario. Responses are provided for both the pre- and post-surveys for the sake of comparison. They are grouped based on the level of government represented by each scenario (school, local, state, and U.S. Supreme Court). In each of the scenarios, there are observable changes in the distribution of proposed responses between pre and post.

For the school safety scenario, fewer students reported that they would do nothing after the course, though fewer also reported that they would build consensus. More students reported that they would contact local authorities, the majority response for both pre and post, but they also became more accurate in identifying either campus police or local administrative officials as their points of contact. In the local government highway construction scenario, there was a marked increase in the percentage of students who would do nothing and decreases in all other actions except for contacting authorities above the level of the city/county and building consensus. In the state marijuana legalization scenario, a great many of the respondents in the pre-survey reported that they would do nothing. Many of these expressed support for legalization, though they did not recognize that there were actions they could take to improve the chances of the bill's passage. Instead they chose not to act. A smaller percentage, but still a supermajority, of respondents reported in the post that they would do nothing after taking the 
course. There were small increases in the percentages that would take individual action, contact authorities, and build consensus. Finally, in the U.S. Supreme Court scenario, many students recognized being able to do very little to affect a change in the outcome of the case. In fact, the percentage saying they would do nothing increased in the post-survey and there set of other proposed actions was reduced to contacting non-local authorities and building consensus. Otherwise, education, individual action, and contacting local authorities were not suggested at all in the post-survey.

Table 1. Actions Proposed by Students in Response to Four Scenarios

\begin{tabular}{|c|c|c|c|c|c|c|c|c|}
\hline Scenario & Nothing & Educate & $\begin{array}{c}\text { Individual } \\
\text { Action } \\
\text { (Personal) }\end{array}$ & $\begin{array}{l}\text { Individual } \\
\text { Action } \\
\text { (Solution } \\
\text { Oriented) }\end{array}$ & $\begin{array}{c}\text { Contact Local } \\
\text { Authorities }\end{array}$ & $\begin{array}{c}\text { Contact Other } \\
\text { Authorities }\end{array}$ & $\begin{array}{c}\text { Build } \\
\text { Consensus }\end{array}$ & $\mathrm{N}$ \\
\hline School Pre & $20 \%$ & 0 & $8 \%$ & 0 & $60 \%$ & $4 \%$ & $12 \%$ & 25 \\
\hline School Post & $16 \%$ & 0 & $11 \%$ & 0 & $68 \%$ & 0 & $5 \%$ & 19 \\
\hline Local Pre & $7 \%$ & $11 \%$ & $7 \%$ & $19 \%$ & $52 \%$ & $15 \%$ & $33 \%$ & 27 \\
\hline Local Post & $20 \%$ & 0 & 0 & $7 \%$ & $33 \%$ & $20 \%$ & $47 \%$ & 15 \\
\hline State Pre & $88 \%$ & $4 \%$ & $4 \%$ & 0 & $12 \%$ & 0 & $4 \%$ & 25 \\
\hline State Post & $73 \%$ & 0 & 0 & $7 \%$ & $7 \%$ & $7 \%$ & $7 \%$ & 15 \\
\hline $\begin{array}{l}\text { Supreme } \\
\text { Court Pre }\end{array}$ & $70 \%$ & $17 \%$ & $4 \%$ & $17 \%$ & $4 \%$ & 0 & $4 \%$ & 23 \\
\hline $\begin{array}{l}\text { Supreme } \\
\text { Court Post }\end{array}$ & $77 \%$ & 0 & 0 & 0 & 0 & $8 \%$ & $15 \%$ & 13 \\
\hline
\end{tabular}

\section{Student Motivations}

For the open-ended questions asking students to explain their motivations for action (or inaction), the emergent coding process produced four persistent themes relevant to student perceptions of their own civic agency, described below.

In the pre-survey, the students expressed a strong tendency overall $[\mathrm{n}=15]$ to place the locus of agency with authority figures, whether campus police (in the case of public safety), 
physicians (in the case of assisted suicide), or government bodies ["if many favor a legislation, it is Congress' job to honor the people's wishes and work to pass the legislation"']. In the postsurvey, however, there was a slight tendency for the locus of agency to diverge by the level of the issue. For the more local issues, students became less inclined to give over agency to authorities ["if I thought that the highway would be harmful, I would want to prevent it from being built, so signing a petition could result in people who proposed the highway changing their minds."]. At the same time, they became slightly more inclined to defer to authority at the state and federal levels ["Ultimately, it's up to the Supreme Court to decide what's the appropriate response"].

In the pre-survey, some students $(n=6)$ placed the locus of agency with others who were not necessarily figures of authority, but rather part of a perceived critical mass. These often undefined "others" could be external to the individual student [e.g. "I'm sure many other people looked into this potential issue when proposing the highway so I don't think it's necessary to bring it up unless there's a substantial chance it will be dangerous"; "I do think that medical marijuana should be legalized, however I do not see it as a massive issue in need of my effort. Especially considering that it already has it from others"], or a larger group of which the student could be a part [e.g. "confronting legal decisions and opposing laws is something I would fear doing on my own; being a small part of or simply supporting a larger group with this purpose would make me feel more comfortable with my opposition and the possible outcome of my opposition"]. Interestingly, this tendency disappeared in the post-survey responses, replaced by either stronger individual action [e.g. "to make my voice heard"] or no action at all [e.g. "by the time I find out, there might not be anything I can do"]. 
The responses collectively suggested the possibility of civic agency as a rational choice, in which students weighed the degree to which the issue affected them personally (interests), with their perceived ability to affect the outcome (beliefs) in order to determine an action (behavior). Especially for the latter two issues, the most common explanation for non-action $(\mathrm{n}=13$ pre; $\mathrm{n}=8$ post) was a lack of personal interest or perceived individual impact [e.g "issues like that are not that important to me", "not passionate about it either way"; "it doesn't affect me"], but low efficacy was a persistent secondary theme [e.g. "I don't concern myself with larger decisions especially if the decision is already set in stone", "I would probably not interfere with this legalization alone unless there is a platform to support that could make a more apparent difference to the state government because of the greater support. If it such a platform did not exist, I would not bother to do so"]. In several cases ( $\mathrm{n}=4)$, students appeared to conduct a full calculus of agency [e.g. "if I thought that the highway would be harmful, I would want to prevent it from being built, so signing a petition could result in people who proposed the highway changing their minds"; or "I believe that it is difficult to always take action on anything that may seem the slightest bit incorrect. But, if something becomes unethical and almost immoral (causing extreme harm to other beings), that is when I would take some kind of action. "].

That calculus of civic agency appeared to differ depending on whether a student was for or against an issue. While the scenarios were carefully crafted to be non-partisan and/or applicable to multiple positions, the students seemed to be more inclined to take action when they perceived their position as being in opposition to the issue being considered; and far less inclined to take action when they saw their position as being in support. The latter tendency was most prevalent in the case of medical marijuana [e.g. "I support legalized medical marijuana and feel as if any actions I took would be counterproductive"; "I do think that medical marijuana 
should be legalized, however I do not see it as a massive issue in need of my effort. Especially considering that it already has it from others"]. There was more mixed support for the issue of physician-assisted suicide, with those opposed suggesting more, or stronger actions than those in favor [e.g. "I cannot influence the supreme court, however I am able to spread awareness about this issue"].

\section{Discussion and Conclusion}

Much research has been done on the gap between intentions and behaviors. Scholars have identified a number of factors that mitigate the distance between intention and behavior, including factors such as prior knowledge, role models (and other normative influences), and other curricular or co-curricular experiences that are confounding variables largely outside the scope of the current study. Similarly, classroom experiences, no matter how active, are indirect experiences of civic life, which have weaker ties to behavior change than direct exposure. Indeed, those students in the present study who expressed direct experience with civic issues outside of the classroom $(\mathrm{n}=2)$ were able to articulate more complex or concrete actions vis a vis the scenarios. Increasing civic engagement is a long-term and iterative venture that extends far beyond a single course. Nevertheless, this study shows how an introductory American government course increases civic agency among students, which is a key linkage between intention and behavior.

In order to act, an individual must both care about acting and know what they can do to effect change. This study focused on whether an introductory American government course can influence the second. The first is a much harder, though not impossible, task for educators. There is clear evidence in this study that such an introductory course in fact builds civic agency. Comparing the pre- and post-surveys, respondents changed both their responses to the scenarios 
and rationales for those responses. There is a sharper focus on actions that are possible in the post-survey responses. In fact, the degree of agency varies with the locus of control in the scenario. Greater proportions of students expressed individual and collective action in the school and local government scenarios. These are venues that are highly personal and offer many avenues for direct engagement. In the state government and U.S. Supreme Court scenarios, however, there is a strengthening of a non-action responses in the post-survey. This is especially the case for the Supreme Court.

The increase in action-oriented responses for the school and local scenarios combined with the decrease for state and federal demonstrates that after the experience of the course, students better understand where they can best effect change as individuals. This fits with a theory of reasoned action, whereby focusing on the actions that are possible makes the pathway toward acting visible and thus can facilitate behavior change (Armitage and Christian 2017; Abraham and Sheeran 2017; Fishbein and Ajzen 2015). Meaning, students' calculus becomes clearer after the course. They can weigh the relative impact of their efforts depending on the means accessible for making their voice heard. Put another way, the course helps students understand where the levers of power lie for individual citizens and how they can use those levers to effect change.

Thus, civic agency is a key linkage between the intention to act and actual civic engagement. It is difficult for a single course to claim that it directly causes an increase in civic activity among students. However, this study demonstrates how one course buttresses the necessary linkage between intent and action. Further, there is preliminary evidence that this course also influences the first part of the action equation, caring. There is a glimmer of evidence of increases in altruism and empathy, which are also important for civic action (Kollmuss and 
Agyeman 2002). This was particularly the case for the medical marijuana and death with dignity scenarios. In justifying their actions, students were able to recognize the needs of others [e.g., "I think medical marijuana can help people who need it," "people who are suffering should be able to choose to have autonomy over their own lives"]. Responses to the campus safety scenario, on the other hand, were more personalized. Thus, future investigations of pro-social incentives (altruism and empathy), as well as the importance of external factors in shaping student agency are warranted.

There are also important limitations to this study. It is one class at one university; thus, the generalizability of the findings is not clear. Using this as a pilot study, an organization like the Consortium for Inter-Campus SoTL Research could expand on this research with a multicampus effort. This may also be possible within large university systems, like in California or New York. There is also a limitation in the marijuana scenario. Pennsylvania had adopted medical marijuana prior to the start of the study (i.e., in 2016). It is possible that students who responded that they would do nothing in that scenario did so because they knew that it was already legal. In combination, the action and reasoning responses suggest that this was not likely the case. Few remarked that medical marijuana was already legal, and many appeared to be responding to marijuana use legalization writ large (including adult-use recreational). Thus, it is unlikely that using this scenario undermined the validity of the results, but it is an important caveat.

This study has important implications for the enterprise of political science education. A prominent and vital cornerstone of our efforts is to develop an informed and active citizenry. This is the case for students majoring in political science, but the discipline has a role to play in leading higher education's related mission. Introductory courses are often the only exposure that 
non-majors will have to the principles of democratic action. This study demonstrates that even a single introductory course can lay the foundation for future civic engagement by increasing student civic agency. The course helps students to clarify the calculus of acting, which is necessary, though not sufficient, for action.

\section{References}

Abel, Martin, Rulof Burger, Eliana Carranza, and Patrizio Piraino. 2019. "Bridging the IntentionBehavior Gap? The Effect of Plan-Making Prompts on Job Search and Employment." American Economic Journal: Applied Economics 11 (2):284-301.

Abernathy, Claire, and Jennifer Forestal. 2019. "Civics Across Campus: Designing Effective Extracurricular Programming." Journal of Political Science Education:1-25.

Abraham, Charles, and Paschal Sheeran. 2017. "Implications of Goal Theories for the Theories of Reasoned Action and Planned Behavior." In Planned Behavior, ed. M. Gross. New York, NY: Routledge.

Anderson, Cameron D., Peter J. Loewen, and R. Michael McGregor. 2018. "Implementation Intentions, Information, and Voter Turnout: An Experimental Study." Political Psychology 39 (5):1089-1103.

Armitage, Christopher J., and Julie Christian. 2017. "From Attitudes to Behavior: Basic and Applied Research on the Theory of Planned Behavior." In Planned Behavior, ed. M. Gross. New York, NY: Routledge.

Assendelft, Laura van. 2008. "“City Council Meetings Are Cool": Increasing Student Civic Engagement Through Service Learning." Journal of Political Science Education 4 (1):8697.

Bandura, Albert. 2006. "Toward a Psychology of Human Agency." Perspectives on Psychological Science 1 (2):164-180.

Barrett, Katherine, and Richard Greene. 2017. "Civic Education: A Key to Trust in Government." In Teaching Civic Engagement Across the Disciplines, ed. E. C. Matto, A. R. M. McCartney, E. A. Bennion and D. Simpson. Washington, DC: American Political Science Association.

Barrett, Martyn, and Bruna Zani, eds. 2015. Political and Civic Engagement: Multidisciplinary Perspectives. London, UK: Routledge. 
Baumann, Zachary D., Kathleen Marchetti, and Benjamin Soltoff. 2015. "What's the Payoff?: Assessing the Efficacy of Student Response Systems." Journal of Political Science Education 11 (3):249-263.

Beaumont, Elizabeth. 2005. "The Challenge of Assessing Civic Engagement: What We Know and What We Still Need to Learn about Civic Education in College." Journal of Public Affairs Education 11 (4):287-303.

Beaumont, Elizabeth, Anne Colby, Thomas Ehrlich, and Judith Torney-Purta. 2006. "Promoting Political Competence and Engagement in College Students: An Empirical Study." Journal of Political Science Education 2 (3):249-270.

Bell, Stephanie, and J. P. Lewis. 2015. "The Place of Civic Engagement in Introductory Canadian Politics and Government Courses in Canadian Universities." Journal of Political Science Education 11 (2):157-173.

Bringle, Robert G., and Patti H. Clayton. 2012. "Civic Education through Service Learning: What, How, and Why?" In Higher Education and Civic Engagement: Comparative Perspectives, ed. L. McIlrath, A. Lyons and R. Munck. New York: Palgrave Macmillan US.

Bryant, Alyssa N., Joy Gaston Gayles, and Heather A. Davis. 2012. "The Relationship between Civic Behavior and Civic Values: A Conceptual Model." Research in Higher Education 53 (1):76-93.

Carey, John M., Gretchen Helmke, Brendan Nyhan, Mitchell Sanders, and Susan Stokes. 2019. "Searching for Bright Lines in the Trump Presidency." Perspectives on Politics 17 (3):699-718.

Carrington, Michal J., Benjamin A. Neville, and Gregory J. Whitwell. 2014. "Lost in translation: Exploring the ethical consumer intention-behavior gap." Journal of Business Research 67 (1):2759-2767.

Clayton, Patti H., Robert G. Bringle, and Julie A. Hatcher. 2012. Research on Service Learning: Conceptual Frameworks and Assessment (Volume 1). Sterling, VA: Stylus Publishing, LLC.

Colby, Anne, Elizabeth Beaumont, Thomas Ehrlich, and Josh Corngold. 2007. Educating for Democracy: Preparing Undergraduates for Responsible Political Engagement. San Francisco, CA: Jossey-Bass.

DeLaet, Debra L. 2016. "A Pedagogy of Civic Engagement for the Undergraduate Political Science Classroom." Journal of Political Science Education 12 (1):72-84. 
Elder, Laurel, Andrew Seligsohn, and Daniel Hofrenning. 2007. "Experiencing New Hampshire: The Effects of an Experiential Learning Course on Civic Engagement." Journal of Political Science Education 3 (2):191-216.

Esen, Berk, and Şebnem Yardımc1-Geyikçi. 2019. "An Alternative Account of the Populist Backlash in the United States: A Perspective from Turkey." PS: Political Science \& Politics 52 (3):445-450.

Faries, Mark D. 2016. "Why We Don't "Just Do It": Understanding the Intention-Behavior Gap in Lifestyle Medicine." American journal of lifestyle medicine 10 (5):322-329.

Fink, L. Dee. 2003. A Self-Directed Guide to Designing Courses for Significant Learning. Norman, OK: University of Oklahoma.

Fishbein, Martin, and Icek Ajzen. 2015. Predicting and Changing Behavior. New York, NY: Routledge.

Flanagan, Constance A., Amy K. Syversten, and Michael D. Stout. 2007. "Civic Measurement Models: Tapping Adolescents' Civic Engagement." Boston, MA: CIRCLE.

Forestiere, Carolyn. 2015. "Promoting Civic Agency Through Civic-Engagement Activities: A Guide for Instructors New to Civic-Engagement Pedagogy." Journal of Political Science Education 11 (4):455-471.

Frederiks, Elisha R., Karen Stenner, and Elizabeth V. Hobman. 2015. "Household energy use: Applying behavioural economics to understand consumer decision-making and behaviour." Renewable and Sustainable Energy Reviews 41:1385-1394.

Glanz, Karen, Barbara K. Rimer, and K. Viswanath, eds. 2008. Health Behavior and Health Education: Theory, Research, and Practice. Fourth ed. San Francisco, CA: Jossey-Boss.

Goldfinger, Johnny, and John Presley, eds. 2010. Educating Students for Political Engagement: A Guide to Implementation and Assessment for Colleges and Universities. Washington, DC: American Association of State Colleges and Universities.

Gould, Jonathan, ed. 2011. Guardian of Democracy: The Civic Mission of Schools. Philadelphia, PA: Leonore Annenberg Center for Civics and the Campaign for the Civic Mission of Schools.

Hatcher, Julie A. 2011. "Assessing civic knowledge and engagement." New Directions for Institutional Research 2011 (149):81-92. 
Hellwege, Julia Marin. 2018. "Left to Their Own Devices: A Student-Centered Approach to Civic Engagement." Journal of Political Science Education:1-24.

Holland, Barbara. 2014. "Strategies for Understanding the Impact of Civic Learning and Teaching." In Civic Learning and Teaching, ed. A. Finley. Washington, DC: Bringing Theory to Practice.

Hosking, Geoffrey. 2019. "The Decline of Trust in Government." In Trust in Contemporary Society, ed. M. Sasaki. Leiden, The Netherlands: Brill.

Huerta, Juan Carlos, and Joseph Jozwiak. 2008. "Developing Civic Engagement in General Education Political Science." Journal of Political Science Education 4 (1):42-60.

Ivanov, Ivan Dinev. 2019. "The Use of Interactive Student Response Software in an Introductory International Relations Course." Journal of Political Science Education:1-18.

Jacoby, Barbara. 2009. Civic Engagement in Higher Education: Concepts and Practices. San Francisco: John Wiley \& Sons.

Kollmuss, Anja, and Julian Agyeman. 2002. "Mind the Gap: Why do people act environmentally and what are the barriers to pro-environmental behavior?" Environmental Education Research 8 (3):239-260.

Kuh, George D. 2008. High-Impact Educational Practices: Why Are They, Who Has Access to Them, and Why They Matter. Washington, DC: Association of American Colleges and Universities.

Latimer, Christopher, and Karen M. Hempson. 2012. "Using Deliberation in the Classroom: A Teaching Pedagogy to Enhance Student Knowledge, Opinion Formation, and Civic Engagement." Journal of Political Science Education 8 (4):372-388.

Levine, Peter. 2019. "New Civic Engagement Section for the American Political Science Association." In Civic Renewal.

Liu, Ruo-Lan, and Pai Ying Lin. 2017. "Changes in Multicultural Experience: Action Research on a Service Learning Curriculum." Systemic Practice and Action Research 30 (3):239256.

Lorenzini, Michelle. 2013. "From Global Knowledge to Global Civic Engagement." Journal of Political Science Education 9 (4):417-435.

Lott, Joe L. II. 2013. "Predictors of Civic Values: Understanding Student-Level and InstitutionalLevel Effects." Journal of College Student Development 54 (1):1-16. 
Malle, Bertram F., Louis J. Moses, and Dare A. Baldwin, eds. 2003. Intentions and Intentionality: Foundations of Social Cognition. Cambridge, MA: MIT Press.

Mansbridge, Jane J. 2017. "Why Do We Need Government? The Role of Civic Education in the Face of the Free-Rider Problem." In Teaching Civic Engagement Across the Disciplines, ed. E. C. Matto, A. R. M. McCartney, E. A. Bennion and D. Simpson. Washington, DC: American Political Science Association.

Matto, Elizabeth C., Alison Rios Millett McCartney, Elizabeth A. Bennion, and Dick Simpson. 2017. Teaching Civic Engagement Across the Disciplines. Washington, DC: American Political Science Association.

Mayhew, Emma. 2019. "No Longer a Silent Partner: How Mentimeter Can Enhance Teaching and Learning Within Political Science." Journal of Political Science Education:1-6.

McCartney, Alison Rios Millett, Elizabeth A. Bennion, and Dick Simpson, eds. 2013. Teaching Civic Engagement: From Student to Active Citizen. Washington, DC: American Political Science Association.

Moely, Barbara E., Sterett H. Mercer, Vincent Ilustre, Devi Miron, and Megan McFarland. 2002. "Psychometric Properties and Correlates of the Civic Attitudes and Skills Questionnaire (CASQ): A Measure of Students' Attitudes Related to Service-Learning." Michigan Journal of Community Service Learning 8 (2):15-26.

Musil, Caryn McTighe. 2009. "Educating Students for Personal and Social Responsibilty: The Civic Learning Spiral." In Civic Engagement in Higher Education, ed. B. Jacoby. San Francisco, CA: Jossey Bass.

National Task Force on Civic Learning and Democratic Engagement. 2012. A Crucible Moment: College Learning and Democracy's Future. Washington, DC: Association of American Colleges and Universities.

Nicholls, Jeananne, and Kurt Schimmel. 2012. "Match/Mismatch of the College Business Student Service-Learning Experiences: Drivers of Perceived Attitude Change, Satisfaction, and Future Volunteering Intentions." Journal of Higher Education Theory and Practice 12 (6):91-99.

Pfeiffer, Ellen, Uta Wehn, Lakshmi Charli-Joseph, Amy M. Lerner, and Kenneth Irvine. 2017. "Training Sustainability Change Agents: Lessons from International Water Education." In Handbook of Theory and Practice of Sustainable Development in Higher Education: Volume 4, ed. W. Leal Filho, U. M. Azeiteiro, F. Alves and P. Molthan-Hill. Cham: Springer International Publishing. 
Rainie, Lee, and Andrew Perrin. 2019. Key Findings About Americans' Declining Trust in Government and Each Other. Pew Research Center, July 22, 20192019 [cited January 20, 2020 2019]. Available from https://www.pewresearch.org/fact-tank/2019/07/22/keyfindings-about-americans-declining-trust-in-government-and-each-other/.

Reason, Robert D., and Kevin Hemer. 2015. "Civic Learning and Engagement: A Review of the Literature on Civic Learning, Assessment, and Instruments." Iowa City, IA: Research Institute for Studies in Education.

Reschly, Amy L., and Sandra L. Christenson. 2012. "Jingle, Jangle, and Conceptual Haziness: Evolution and Future Directions of the Engagement Construct." In Handbook of Research on Student Engagement, ed. S. L. Christenson, A. L. Reschly and C. Wylie. Boston, MA: Springer US.

Sheeran, Paschal, and Thomas L. Webb. 2016. "The Intention-Behavior Gap." Social and Personality Psychology Compass 10 (9):503-518.

Torney-Purta, Judith, Julio C. Cabrera, Katrina Crotts Roohr, Ou Lydia Liu, and Joseph A. Rios. 2015. "Assessing Civic Competency and Engagement in Higher Education: Research Background, Frameworks, and Directions for Next-Generation Assessment." ETS Research Report Series 2015 (2):1-48.

Wiggins, Grant. 1990. "The Case for Authentic Assessment." Practical Assessment, Research \& Evaluation 2 (2):1-6.

Wukich, Clayton, and Michael D. Siciliano. 2014. "Problem Solving and Creativity in Public Policy Courses: Promoting Interest and Civic Engagement." Journal of Political Science Education 10 (3):352-368.

Yanus, Alixandra B., Martin J. Kifer, Paul Namaste, Sadie Leder Elder, and Joe Blosser. 2015. "Turning Civic Education into Engagement: Evaluating the Efficacy of the Democracy USA Project." Journal of Political Science Education 11 (3):279-300. 